\title{
IMPLEMENTASI MANAJEMEN STRATEGIK DALAM PENGEMBANGAN BUDAYA ORGANISASI PADA PERGURUAN TINGGI ISLAM: Studi Kasus di UIN Maliki Malang
}

\author{
Aries Musnandar \\ Fakultas Ekonomi Bisnis Universitas Brawijaya Malang \\ Telp.0811362625, email: raries.m1@gmail.com
}

\begin{abstract}
This article elucidated the strategic management of developing Islamic culture in the State Islamic University of Maulana Malik Ibrahim (UIN Maliki) Malang. Strategic management could be applied to every organization size and to every organization level. The strategic management applied from the top to the lower level units. The development of Islamic culture is an important part of the mission and vision of UIN Maliki Malang which has experienced on going metamorphosis starting from IAIN, STAIN, and UIN Maliki Malang. This case study used a qualitative research method. The reseacher found that, the changes of UIN Maliki Malang were relatively fast and this development certainly needed a careful handling to improve the quality of the noble cause of education in an Islamic institution. However, the implementation of Islamic values has still a big gap between values and reality in its application. Control function of management concept should be applied to ensure the embodying values to Campus or people. The organizational leadership in the institution of UIN Maliki Malang needed to be more empowered and implemented in accordance with the principles of shining noble teachings of the Qur'an and Hadith. The available resources must be utilized as much as possible. Finally, it concluded that the concepts of quality improvement management with various models and approaches that were available should be also embedded in the form of Islamic values.
\end{abstract}

Artikel ini memapaparkan tentang manajemen strategik pada pengembangan budaya Islami di perguruan tinggi Islam, studi kasus di Universitas Islam 
Negeri Maulana Malik Ibrahim (UIN Maliki) Malang. Manajemen strategik bisa diterapkan pada segala ukuran organisasi dan pada setiap level organisasi dan didalam jenjang organisasi. Manajemen strategik dimulai dari level teratas dari organisasi strategik hingga tingkat paling bawah pada unit-unit organisasi. Pengembangan budaya Islami merupakan bagian penting dari manajemen strategik dalam upaya mencapai visi dan tujuan organisasi UIN Maliki Malang yang telah mengalami perubahan mulai dari institut cabang Surabaya (IAIN) sekolah tinggi (STAIN), dan universitas (UIIS) hingga seperti sekarang ini (UIN Maliki Malang). Dengan menggunakan studi kasus dibawah payung metode penelitian kualitatif, penulis menemukan bahwa perubahan organisasi UIN Maliki Malang relatif sangat cepat dan pengembangan (perubahan) ini tentu membutuhkan penanganan yang cermat dan hati-hati untuk meningkatkan kualitas tujuan mulia pendidikan pada organisasi Islam seperti di UIN Maliki Malang. Namun demikian, implementasi nilai-nilai Islam di lapangan masih terdapat kesenjangan cukup besar antara nilai dan kenyataan. Fungsi pengawasan semestinya diterapkan untuk memastikan nilai-nilai tersebut melekat erat di kampus dan sivitas akademika. Kepemimpinan organisasi di lembaga UIN Maliki Malang tampaknya perlu lebih diberdayakan dan diterapkan sesuai prinsip-prinsip ajaran mulia yang bersumber pada al-Quran dan Hadist. Berbagai sumber yang tersedia masih perlu dimanfaatkan seoptimal mungkin untuk mencapai tujuan dari perubahan organisasi tersebut. Pada akhirnya, perubahan ini meliputi pula konsep manajamen peningkatan mutu dengan berbagai model dan pendekatan yang dimungkinkan dalam bentuk nilai-nilai Islam.

Key words: strategic management, change management standar, organization culture, cultural development of Islamic values

\section{Pendahuluan}

Sonhadji (2003: 1) menilai bahwa manajemen organisasi dalam meningkatkan efektifitas dan efisiensi pendayagunaan sumber dayanya butuh diberlakukan suatu model manajemen terukur. Dalam konteks manajemen modern dikenal istilah manajemen strategik yakni satu model manajemen yang dapat digunakan sebagai upaya organisasi untuk bertumbuh dan berkembang secara efektif dalam mencapai tujuan yang diharapkan. Organisasi yang baik mesti melakukan perencanaan dengan akurat dan tentu mendasari pelaksanaan kegiatan organisasinya pada perencanaan yang telah diformulasikan secara seksama.

Manajemen strategik didefinisikan sebagai proses formulasi dan implementasi rencana, dan kegiatan terkait hal-hal vital, penting, pervasif, berkesinambungan bagi suatu organisasi secara keseluruhan. Jadi, manajemen strategik meliputi formulasi strategi dan implementasi strategi (Sharplin dalam 
Sonhaji, 2003: 1) Jika manajemen strategik dalam dunia industri dan bisnis dimanfaatkan untuk memprediksi kecenderungan pasar dan peluang bisnis serta upaya meningkatkan daya saing, keunggulan produk dan manajemen perusahaan, maka dalam pendidikan dipakai mengefektifkan berbagai sumber daya untuk pencapaian tujuan pendidikan.

Ukuran (size) dan level dalam organisasi bervariasi, ada ukuran organisasi yang besar, sedang (menengah) dan kecil. Manajemen strategik bisa diterapkan ke ukuran organisasi sebesar apapun dan pada tingkat manapun didalam organisasi (within organization). Manajemen strategik mulai dilakukan pada tingkat paling atas yang disebut organization strategic hingga pada level paling bawah dalam unit-unit organisasi. Di dunia bisnis dikenal istilah corporate management strategic, sedangkan di level bawah terdapat manajemen strategik bagian / fungsi keuangan dan seterusnya yang tidak terlepas dari strategik level atas (Sharplin, 1985: 5-8).

Dari perspektif diatas lantas kita dapat menggunakan pendekatan manajemen strategik ini kedalam perspektif lain seperti pada situasi dunia dakwah. Model manajemen strategik yang dimanfaatkan untuk kepentingan dakwah pada hakekatnya ditujukan bagi efektivitas kegiatan dan pengalokasian sumberdaya yang tersedia. Hasil akhir diharapkan dapat mencapai tujuan dakwah secara maksimal.

Organisasi dalam ukuran apapun baik dalam skala kecil maupun makro paling tidak ada tiga aspek penting yang diperlukan bagi bertumbuh-kembangnya budaya organisasi pada suatu lembaga, tak terkecuali di lembaga pendidikan Islam. Ketiga aspek tersebut meliputi: (1) nilai-nilai yang diterima dalam organisasi; (2) pemberlakuan sistem untuk menanam-suburkan nilai-nilai organisasi tersebut; dan (3) kepemimpinan organisasi dalam rangka untuk mewujudnyatakan nilai-nilai yang disepakati itu melalui penerapan sistem menuju budaya organisasi yang didambakan.

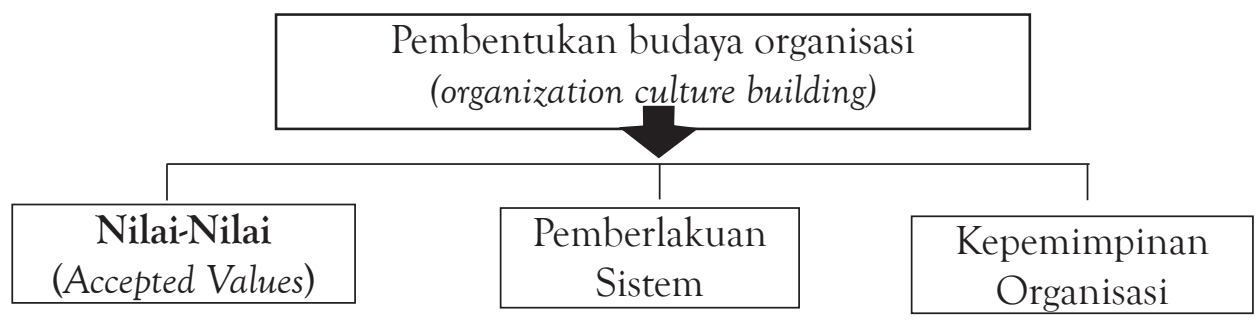

Gambar 1 Hubungan Nilai, Sistem dan Leadership Bagi Pembentukan Budaya dalam Suatu Organisasi (diadopsi dan dikembangkan dari Sonhadji, 2003: 10-20). 
Setiap nilai yang telah disepakati oleh anggota organisasi memerlukan instrumen dalam mengejawantahkannya. Proses penjabaran nilai-nilai, yang disusul dengan upaya perwujudan nilai-nilai memerlukan suatu sistem serta kepemimpinan organisasi agar dapat dijewantahkan dalam budaya organisasi. Institusionalisasi nilai merupakan syarat bagi membuminya nilai-nilai tersebut pada budaya organisasi. Para pakar teori organisasi menyadari pentingnya peran budaya dalam dinamika organisasi. Budaya sebagai suatu variabel independen yang mempengaruhi sikap dan perilaku setiap anggota organisasi dapat dimulai sejak munculnya ide pelembagaan (pembentukan organisasi). Tatkala organisasi terbentuk perilaku setiap anggota dapat melebur dalam perilaku organisasi itu secara lebih luas (Owens 1989, Luthans, 1992, Sonhadji 2003).

Di Universitas Islam Negeri Malik Maulana Ibrahim atau yang lebih dikenal dengan UIN Maliki Malang perubahan bentuk organisasi yang dialaminya disamping mencuatkan persoalan akademik muncul juga persoalan budaya organisasi. Sebagai organisasi lembaga pendidikan Islam (LPI) di tingkat perguruan tinggi, tentunya setiap aturan/peraturan, norma, tradisi dan budaya organisasi UIN mesti tidak terlepas dari nilai-nilai yang bersandar pada ajaran Islam.

Perubahan status yang dialami UIN Maliki Malang misalnya, mulai dari IAIN di bawah Surabaya, STAIN, UIIS dan sekarang UIN Maliki Malang, tidak hanya mewujudkan tradisi baru tetapi pasti saja ada tradisi-tradisi lama yang tetap dipertahankan. Suasana kekeluargaan, pikiran khuznudzan atau senantiasa berpikir positif dan iklim keterbukaan merupakan budaya dan kebiasaankebiasaan Islami yang mesti terus dipelihara dan ditumbuh-kembangkan di dalam organisasi Islam (UIN Maliki Malang) meski terjadi perubahan yang cukup mendasar pada bentuk organisasi tersebut (Raharjo, 2004 : 269).

Upaya mewujudnyatakan nilai budaya Islami di UIN Maliki Malang yang sesuai dengan harapan visi dan misi organisasi kiranya perlu ditelaah apakah organisasi itu telah berjalan menurut standar manajemen perubahan yang tepat? Apakah konsep dan model manajemen strategik telah dijadikan acuan oleh pihak jajaran pimpinan di UIN Maliki Malang yang melandasi praktek perubahan organisasi yang sedang berlangsung? Berdasarkan latar uraian di atas penulis tertarik mengulas tentang "Implementasi Konsep Manajemen Strategik Dalam Pengembangan Budaya Islami pada Perguruan Tinggi Islam: Studi Kasus di UIN Malang”. 


\section{Pembahasan}

1. Perubahaan Organisasi sebagai Suatu Kebutuhan

Renald Kasali (2006) mengungkapkan bahwa perubahan adalah keniscayaan dan setiap organisasi apapun selalu mengikuti perkembangan yang terjadi disekitarnya yang memungkinkan organisasi tersebut melakukan perubahan. Proses perubahan dilakukan agar kehidupan organisasi dapat terpelihara, berkelanjutan dan lebih bermanfaat. Apabila organisasi mampu berubah secara tepat, maka organisasi akan memiliki usia panjang bertahan dalam lingkungannya. Organisasi kampus seperti Oxford University di Inggris, Leiden University di Belanda, Harvard University, dan Massachuset Institue of Technology di Amerika Serikat, Universitas Al-Azhar di Mesir, merupakan organisasi pendidikan yang bertahan ratusan tahun dan masih memiliki produk-produk pendidikan yang kompetitif. Hal ini hanya mungkin terjadi manakala organisasi pendidikan tersebut meninggalkan karakteristik organisasi tradisional dan menerapkan konsep organisasi baru yang modern melalui telaah filosofis terkait perkembangan yang merubah paradigma hidup masyarakat.

Perkembangan situasi dan kondisi yang terjadi diluar organisasi memengaruhi organisasi untuk membuat konstruk organisasi lama (bersifat tradisional) bermetamorfosis menjadi suatu organisasi baru. Perubahan organisasi dimungkinkan manakala iklim, suasana, aturan dan sistem yang ada tidak lagi mampu mengakomodasi berbagai perkembangan dan tuntutan dari luar organisasi, sehingga perlu segera dilakukan perubahan. Disamping itu, situasi internal organisasi yang kurang kondusif bagi kemajuan oganisasi juga dapat menjadi faktor perlunya terjadi perubahan organisasi.

Dalam konteks ini pemahaman tentang seluk beluk organisasi menjadi hal yang mendasar, terutama terkait dengan implementasi konsep manajemen. Manajer senantiasa mengantisipasi perubahan-perubahan dalam lingkungan yang akan mensyaratkan penyesuaian-penyesuaian disain organisasi diwaktu akan datang. Gambaran tentang perubahan dari organisasi lama ke organisasi baru yang membawa serta berbagai karakteristik khusus antara kedua tipe organisasi tersebut dipaparkan sebagai berikut: 
Tabel Perbedaan karakteristik organisasi tradisional dan baru (diadapatasi dari Kasali 2006 dan Musnandar, 2011)

\section{Organisasi tradisional}

Stabil

Tidak fleksibel

Berpusat pada pekerjaan

Berorientasi individual

Pekerjaan yang permanen

Berorientasi pada perintah

Manajer selalu membuat

keputusan

Berorientasi pada aturan

Lingkungan kerja yang relatif

homogen

Jam kerja didefinisikan sebagai

$9-5$

Hubungan yang hirarkhis

Fasilitas kerja ada pada jam-jam tertentu

\section{Organisasi Baru}

Dinamis

Fleksibel

Berpusat pada keterampilan

Pekerjaan di definisikan sebagai

tugas

- tugas yang harus dikerjakan

Berorientasi tim

Pekerjaan yang temporal

Berorientasi pada pelibatan

Partisipasi seluruh pekerja dalam

pengambilan keputusan

Berorientasi pada pelanggan

Diversifikasi lingkungan kerja

Tidak ada batas waktu kerja

Hubungan dua arah dan jaringan

Kerja dimana saja dan kapan saja

\section{Konsep Menangani Perubahan (Standar Manajemen Perubahan)}

Perubahan-perubahan lingkungan dan perkembangan sosial seperti iklim demokrasi, kemajuan sains dan teknologi disertai dinamika internal organisasi turut andil secara optimal dalam membentuk organisasi baru dan meninggalkan organisasi tradisional. Cara menangani perubahan organisasi memerlukan berbagai pendekatan atau cara yang dapat dilakukan bagi organisasi yang berubah (Kasali, 2006). Cara pertama adalah konsep perubahan reaktif dan yang kedua program perubahan yang direncanakan. Pada cara pertama biayanya murah dan sederhana serta ditangani secara cepat, di mana manajer akan memberikan reaksi setelah masalah terjadi. Dalam konteks organisasi perguruan tinggi misalnya, bila peraturan pemerintah baru mensyaratkan perguruan tinggi untuk mempunyai sejumlah guru besar dalam jumlah tertentu, maka sang manajer (Rektor) bisa mendapatkannya dari perguruan tinggi lain yang sudah dikenal.

Pendekatan kedua disebut juga sebagai proses produktif, Thomas dan Bennis (dalam Kasali, 2006) mendefinisikan perubahan yang direncanakan 
tersebut sebagai perencanaan dan implementasi inovasi struktural, kebijaksanaan secara sengaja. Pendekatan ini tepat bila keseluruhan atau sebagian besar satuan organisasi menyiapkan diri untuk menyesuaikan dengan perubahan. Berbagai perubahan tersebut kemudian melahirkan berbagai konsep tentang organisasi, mulai dari organisasi yang sangat mengandalkan pemimpin sampai dengan organisasi yang paling tidak mengandalkan pemimpin. Bermacam tipe atau jenis kepemimpinan organisasi tersebut dapat dijelaskan sebagai berikut:

1. Autocracy adalah organisasi yang mengandalkan "kekuatan" pemimpin. Kewenangan pemimpin tinggi, bila pemimpin tidak mengijinkan maka tidak boleh dilakukan begitu sebaliknya.

2. Egalitarianism. Pada organisasi ini seluruh keputusan ada di tangan anggota organisasi, hampir tidak diperlukan pemimpin, tugas pemimpin hanya memfasilitasi saja terhadap diambilnya sebuah keputusan.

3. Sedangkan diantara autocracy dan egalitarianism ada organisasi bureocracy (birokrasi), system, decentralization (desentralisasi), collegialism dan federations (federasi). Jenis organisasi birokrasi berstruktur hirarkhis, masing-masing orang mengepalai sub organisasi tertentu, satu sub organisasi kemungkinan akan memiliki sub-sub organisasi yang lain. Organisasi birokrasi bersifat sentralisasi. System merupakan jenis organisasi yang mensinkronkan proses pada satu sub bagian (orang) dengan sub bagian (orang lain) sehingga membentuk suatu proses yang berjalan baik. Sinkronisasi mengarah untuk mencapai tujuan yang lebih besar dari organisasi. Desentralisasi merupakan jenis organisasi yang bersifat setara antara satu sub organisasi dengan sub organisasi lain dalam satu organisasi. Masing-masing satu sub organisasi dipimpin oleh satu orang pemimpin. Masing-masing pimpinan sub organisasi bersifat setara. Organisasi Collegialism merupakan organisasi yang memiliki struktur kolegial dalam mencapai tujuannya. Pada jenis organisasi ini kedudukan orangorang yang ada di dalam organisasi lebih bersifat setara, yang mana hubungan sesama anggota organisasi layaknya kolega. Sedangkan pada organisasi Federasi, pemimpin pada tataran sub organisasi memiliki wewenang mutlak layaknya pemimpin pada organisasi utama (Musnandar, 2011: 166-167)

Penjelasan tentang tipe atau jenis kepemimpinan organisasi yang dipaparkan dalam tulisan ini pada bagian selanjutnya akan dihubungkan 
dengan perubahan organisasi yang terjadi di UIN Maliki Malang. Penulis mencoba untuk mengungkapkan perubahan organisasi yang ada di UIN Maliki Malang paling tidak dalam dua perspektif yakni autocracy dan egalitarianism. Acuan dan konsep yang digunakan dalam implementasi manajemen strategik juga terkait dengan tipe kepemimpinan.

\section{Budaya Organisasi \& Manajamen Strategik \\ Budaya Organisasi}

"Hai manusia, Sesungguhnya Kami menciptakan kamu dari seorang laki-laki dan seorang perempuan dan menjadikan kamu berbangsa - bangsa dan bersuku-suku supaya kamu saling kenal-mengenal. Sesungguhnya orang yang paling mulia diantara kamu disisi Allah ialah orang yang paling taqwa diantara kamu. Sesungguhnya Allah Maha mengetahui lagi Maha Mengenal" (QS. Al Hujurat: 13).

Ayat ini mempunyai makna bahwa manusia diciptakan Allah Subhannahu wa ta'ala dari laki-laki dan perempuan dan akhirnya memiliki kebudayaan dunia yang berkaitan tentang tata cara hidup masing-masing dari mereka. Namun Allah mengingatkan agar manusia yang bertaqwa mengikuti perintah Allah dan menjauhi larangan Nya untuk menjadi manusia yang paling mulia. Dalam mencapai derajat taqwa dan menjadi manusia sekaligus, tentu tidak terlepas dari interaksi dengan orang lain dan alam disekitarnya. Kegiatan interaksi timbal balik antar manusia dengan lingkungan merupakan peristiwa sosial yang berujung pada pengayaan budaya.

Kata budaya berasal dari bahasa Sansekerta yakni buddhayah, bentuk jamak dari buddhi yang diartikan budi-akal atau biasa dikaitkan dengan akal budi manusia, menghasilkan karya-karya. Sedangkan dalam bahasa Inggris budaya dan kebudayaan disebut culture, asal kata latin Colere, yaitu mengolah atau mengerjakan, diartikan juga sebagai bertani atau mengolah tanah. Sementara kita sering menggunakan kata kultur untuk menerjemahkan arti culture. Dalam kamus besar Bahasa Indonesia, budaya (culture) diartikan sebagai: pikiran, adat istiadat, sesuatu yang sudah berkembang, sesuatu yang menjadi kebiasaan tampaknya sukar diubah (Departemen Pendidikan dan Kebudayaan, Kamus Besar Bahasa Indonesia, 1991: 149).

Dalam kehidupan sehari-hari, orang biasa mengkaitkan pengertian budaya dengan tradisi-tradisi. Oleh karena itu, kemudian tradisi diartikan sebagai perilaku, sikap dan kebiasaan dari masyarakat yang nampak dalam perilaku sehari-hari yang telah menjadi kebiasaan dari kelompok dalam masyarakat tertentu (Indrafachrudi, 1994: 20). 


\section{Perubahan dan Pengembangan Budaya}

Kehidupan di dunia bersifat relatif, tidak langgeng dan selalu terjadi dinamika berujung pada perubahan. Kehidupan masyarakat akan mengalami perubahan di lingkungannya, baik lingkungan sistem ekonomi, politik, sosial, budaya dan sistem lainnya. Dalam konteks ini perubahan budaya pada masyarakat merupakan hal lumrah dan logis. Budaya adalah aset bangsa. Apabila dikelola baik akan bermanfaat bagi pembangunan karakter dan jati diri bangsa.

Sharplin dalam Sonhadji (2003: 40) mengungkapkan bahwa tingkat homogenitas masyarakat amat kuat mempengaruhi perubahan budaya. Pertama, jika suatu komunitas masyarakat besar dan kompleks, perubahan budaya dalam komunitas itu semakin sulit dibandingkan komunitas kecil dan sederhana. Kedua, perubahan budaya cenderung semakin sulit dalam masyarakat dengan homogenitas budaya yang tinggi dibandingkan dengan masyarakat yang heterogen. Proses terjadinya perubahan dan pengembangan budaya dapat berlangsung cepat, mudah dan sesuai harapan. Sharplin dalam Sonhaji (2003: 41) menyebut tentang tingkat kesulitan mengubah kultur atau budaya tergantung pada dua dimensi yakni kompleksitas atau tingkat homogenitas budaya dan ukuran besar kecilnya organisasi.

Tingkat homogenitas budaya adalah derajat sampai dimana nilai dan kepercayaan dianut oleh suatu organisasi secara luas dan ajeg yang dicerminkan oleh pola perilaku anggota-anggota dalam organisasi tersebut. Model ini menurut Sharplin dalam Sonhadji (2003: 41) dilandasi oleh dua premis. Jika suatu organisasi kompleks dan besar, perubahan budaya dalam organisasi semakin sulit dibandingkan organisasi yang kecil dan sederhana. Kedua, perubahan kultur cenderung semakin sulit dalam suatu organisasi dengan homogenitas budaya tinggi dibandingkan dengan organisasi yang heterogen. Paparan di atas berlaku pula bagi pengembangan budaya organisasi.

Fenomena tersebut menyiratkan bahwa perubahan organisasi dapat ditunjang dengan baik tatkala kondisi budaya organisasi kondusif untuk dimulainya proses perubahan organisasi yang diharapkan. Perubahan organisasi menyangkut perihal pengembangan budaya yang dibutuhkan. Dalam konteks ini jikalau suatu organisasi akan mewujudnyatakan ide-ide, gagasan atau rencana organisasi maka hal utama dan pertama menjadi perhatian adalah tingkat kesiapan para anggota organisasinya. Readiness atau kesiapan dan kematangan (maturity) dari anggota-anggota organisasi dalam menerima perubahan yang telah direncanakan menjadi bagian penting terjadinya proses perubahan dalam 
organisasi secara tepat dan sesuai harapan. Sebaliknya, jika kematangan dan kesiapan anggota organisasi belum sesuai dengan budaya yang diinginkan guna tercapainya tujuan visi dan misi organisasi, maka proses pengembanganakan mengalami persoalan yang cukup menyita perhatian. Alhasil, apa yang telah direncanakan tidak akan tercapai.

Seperti diiungkap oleh John Lewis Gillin dan John Philip Gillin dalam Talizuduhu Ndraha (1997: 88-89) bahwa gejala budaya adalah menyangkut ekspresi alami tentang cara berkehidupan (perilaku) dan pandangan (pemikiran). Oleh karena itu, tradisi dan kebiasaan yang sudah mendarah daging dalam suatu organisasi dapat mempengaruhi organisasi baik dalam arti positif maupun negatif terhadap upaya-upaya menggapai tujuan yang diharapkan.

\section{Konsep Manajemen Strategik}

"Untuk tiap-tiap umat diantara kamu, Kami berikan aturan dan jalan yang terang”. (QS. al Maidah: 48)

"Dan hendaklah ada di antara kalian sekelompok orang yang menyeru kepada kebaikan, menyuruh kepada yang makruf, dan mencegah dari yang mungkar.Dan itulah mereka orang-orang yang beruntung."(Ali Imran: 104)

Mencermati makna yang dalam dari kandungan ayat-ayat di atas meyakinkan kita bahwa setiap umat telah diberikan petunjuk yang jelas dan terukur dalam menempuh hidup dan kehidupan di dunia. Persoalan yang paling mendasar sebenarnya adalah bahwa tidak semua umat manusia "mau mengerti dan berkeinginan untuk mengerti” tentang kebenaran yang telah diturunkan Allah kepada umat manusia baik yang tersurat (melalui al Qur'an) maupun tersirat (melalui Sunnatullah termasuk ilmu pengetahuan).Ilmu yang berkembang sekarang ini juga atas izin Allah karena segala sesuatu yang terjadi di dunia ini atas kehendak, iradat dan sepengetahuan Allah. Hanya saja, sebagaimana disitir dalam banyak ayat al Quran bahwa sedikit manusia yang bersukur atas nikmat Allah sementara banyak manusia yang tidak bersyukur atas segala karunia dan nikmat yang diberikan Allah tersebut, sehingga mereka dalam kesesatan yang nyata baik di dunia apalagi di akherat kelak. Setiap Sunnatullah termasuk ilmu pengetahuan yang diberikan Allah bagi mereka yang tidak bersyukur tidak digunakan untuk meningkatkan taqwa kepada Allah. Alhasil, kehidupan mereka pun sia-sia dimata Allah. Padahal dalam konteks ini orang yang berilmu pengetahuan derajatnya diangkat lebih tinggi dari pada manusia yang tidak memiliki ilmu sebagaimana al Quran Surat alMujadilah \{58\}: 11) Allah akan mengangkat orang yang beriman diantara kamu dan orang berilmu beberapaderajat. Kemudian Allah swt berfirman, Dan katakanlah 
, "Ya Tuhanku, tambahkanlah aku ilmu" (QS: Thaha \{20\}: 1140. Lalu Allah juga berfirmanpada (QS: al Zumar \{39\}: 9). Katakalnlah, "Apakah sama orang-orang yang mengetahui dengan orang-orang yang tidak mengetahui?"

Sebagaimana dijelaskan dalam sejumlah ayat dalam al Quran bahwa Allah telah menjadikan kehidupan alam semesta ini secara harmonis dan seimbang. Apabila kita dapat mengambil hikmah dengan baik untaian ilmu yang terkandung dari penciptaan alam semesta termasuk kehidupan di dunia ini, maka muncul keyakinan dan bahkan keimanan kita akan dapat bertambah meyikini keberadaan dan kekuasaan Allah. Secara sunatullah dapat dikatakan bahwa segala problem dunia telah disiapkan oleh Allah cara dan jalan keluarnya. Setiap amal sholeh yang berlandaskan ketaqwaan pasti ada ganjarannya, sebagaimana dalam ajaran Islam menyebutkan bahwa setiap penyakit pasti ada obatnya kecuali penyakit kematian.

Berbagai ragam persoalan pun pasti ada cara dan jalan jalan keluar untuk mengatasi masalah tersebut. Termasuk dalam konteks ini adalah masalah yang menyangkut kehidupan organisasi yang para anggotanya terdiri dari kumpulan manusia Sejumlah konsep, pendekatan atau model manajemen modern telah berhasil melahirkan produk-produknya dalam upaya meningkatkan efektivitas kerja sumber dayadalam organisasi. Salah satu konsep dan model itu adalah manajemen strategik. Firman Allah dalam al Qur'an Surat al Hasyr : 18 yang berbunyi :

"Hai orang-orang yang beriman, bertakwalah kepada Allah dan hendaklah Setiap diri memperhatikan apa yang telah diperbuatnya untuk hari esok (akhirat); dan bertakwalah kepada Allah, Sesungguhnya Allah Maha mengetahui apa yang kamu kerjakan".

Pemahanan atas kandungan ayat al Quran di atas mengajak manusia beriman untuk terus menerus meningkatkan taqwa. Manusia membuat perencanaan dalam hidup dan kehidupan dilanjutkan dengan penerapannya. Setelah melakukan semua itu kita (manusia) diminta tetap bertaqwa dan menyerahkan apa yang telah kita kerjakan dengan sungguh-sungguh itu kepada Allah semata, karena hanya kepadaNya kita bertawakal mengharap ridho Nya dalam segala kerja dan pekerjaan kita.

Manusia yang terwadahkan dalam dinamika kehidupan organisasi memiliki tipe, karakter, cirri khas dan keunikan masing-masing. Organisasi yang ingin terus diakui dan terjaga keberlangsungannya tentu tidak tinggal diam atas perkembangan pesat dan cepat yang terjadi disekitarnya. Oleh karena itu sejumlah pakar manajemen telah mengantisipasinya dengan sejumlah temuan dan referensi untuk mengatasi berbagai ragam persoalan manajemen 
termasuk dalam perubahan organisasi yang memang tidak dapat dihindari sebagai akibat perkembangan jaman seperti diurai di atas.

Igor, McDonnell (1990), Sharplin, (1985), Freeman (1995), Sonhadji (2003) dan Sondang (2005) sepakat bahwa manajemen strategik mesti dilakukan oleh pimpinan teratas (the top management level) dari suatu organisasi. Keterlibatan pimpinan tidak hanya pada landasan formulasi strategi yang ideal terkait erat dengan visi dan misi organisasi, tetapi yang tidak kalah pentingnya adalah pada tataran praksis implementasinya. Praktek implementasi tersebut terdiri dari:

\section{Menformulasikan Strategi}

Dalam memformulasikan strategi, yang pertama perlu dirumuskan adalah rumusan pernyataan misi organisasi. Begitu misi ditentukan kekuatan atau strengths dan kelemahan (weaknesses) organisasi serta peluang dan ancaman dalam linmgkungan haruslah dikaji secara cermat dan akurat atau dilakukan pengukuran (asesmen) dengan seksama. Setelah itu baru ditentukan tujuantujuan khusus dan strategi organisasi untuk mencapai tujuan tersebut sesuai dengan hasil asesmen yang telah dilakukan. Dengan demikian, formulasi strategi melibatkan aliran informasi baik berasal dari dalam maupun dari luar organisasi (lingkungan).

Hal yang perlu diingat adalah bahwa formulasi strategi berada pada tataran perencanaan (planning), sering dikenal dengan istilah strategic planning (perencanaan strategik). Strategi adalah rencana yang menyangkut hal-hal penting dan vital yang dapat mempengaruhi secara signifikan (Sharplin 1985: 6). Perencanaan ini biasanya bersifat luas dan jangka panjang.

Salah satu sumbangan pokok pelaksanaan manajemen strategik ialah bahwa pimpinan dapat memeriksa kemana arah yang dituju dari organisasi. Keputusan strategik adalah tindakan yang disengaja untuk mengadakan suatu pengendalian terhadap keadaan organisasi di masa depan dan di masa sekarang. Dalam menentukan arah organisasi pemimpin senantiasa memperhatikan pihakpihak terkait dan berkepentingan yang dalam konteks perguruan tinggi dapat terdiri dari dua sisi baik internal yaitu sivitas akademika maupun eksternal yakni regulator pendidikan (pemerintah). Penentuan arah ini merupakan langkah awal sebelum disusun suatu perumusan strategi (Freeman, 1995: 97).

Analisis yang mencakup pula asesmen terhadap faktor eksternal dan internal adalah kegiatan penting dalam perumusan strategi dalam tataran manajemen strategik. Demikian pentinganya kegiatan analisis ini sehingga 
melahirkan metode analisis KeKePan yang merupakan singkatan dari Kekuatan, Kelemahan, Peluang dan Ancaman (Musnandar, 2007) atau lebih dikenal dengan istilah SWOT (Strength, Weakness, Opportunity dan Threat). Metode SWOT ini sangat membantu pimpinan dalam memformulasikan strategi organisasi.

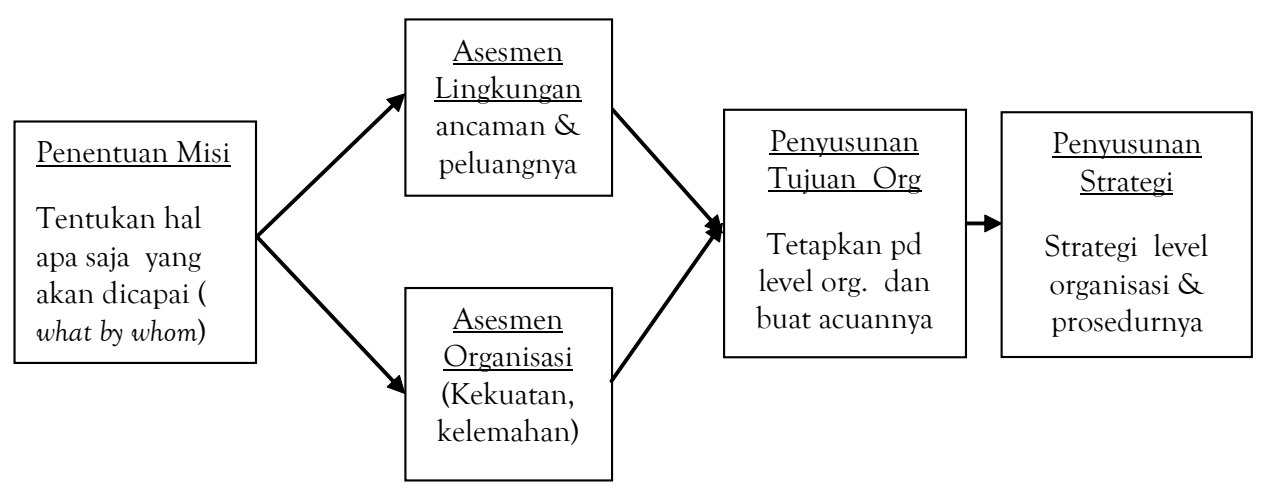

Gambar 3 Strategi Formulasi (diadopsi dari Sonhadji 2003: 2)

Gambar di atas menujukkan penyusunan strategi organisasi dilakukan secara seksama dan menyeluruh tidak hanya melibatkan aspek internal.Tetapi juga berupaya mengukur dan mengkaji aspek eksternal agar menghasilkan strategi yang tepat sasaran. Kedua aspek internal dan eksternal itu bagian dari perhatian pemangku kebijakan organisasi dalam menyusun strategi organisasi.

\section{Mengimplementasikan Strategi}

Setelah perumusan strategi dilakukan dengan menghasilkan sejumlah strategi organisasi maka tahap berikutnya adalah melakukan implementasi strategi, cara mencapai tujuan dan sasaran dalam bentuk strategi implementasi yang selanjutnya diperinci ke dalam kebijakan, program operasional dan kegiatan. Lewis (1983) mengungkap perlunya melakukan penetapan programprogram strategik yang berguna bagi pencapaian tujuan. Program-progran tersebut di elaborasi atau didapat dari sejumlah strategi organisasi yang telah berhasil dirumuskan. Para ahli lainnya seperti Sharplin (1985), Ansoff, Edward (1990) serta Pearce \& Robinson (1991) juga menekankan pentingya mengimplementasikan strategi yang telah diformulasikan tersebut kedalam unit-unit atau fungsi-fungsi yang terdapat dalam organisasi.

Strategi implementasi bersifat menterjemahkan pemikiran dalam renstra 
(rencana strategik) ke dalam tindakan operasional sehari hari sebagaimana yang diungkap oleh Akdon (2006) bahwa kegiatan seluruh komponen tersebut dikarenakan:
a. Memperjelas makna dan hakekat Renstra
b. Antisipasi keadaan / lingkungan yang akan datang
c. Memberikan dorongan dan acuan bagi yang melaksanakan
d. Memberikan kesatuan pandangan atau penyamaan persepsi anggota
e. Mempermudah pengelolaan berdasarkan kemampuan internal organisasi.

Kemudian, untuk mengkoordinasikan semua hal di atas yang terkait Renstra perlu komitmen dari pimpinan tertinggi. Komitmen pemimpin menjelaskan secara gamblang kepada seluruh anggota organisasi mengenai outcome organisasi yang harus dicapai. Namun komitmen pemimpin saja tidak cukup karena tidak bersifat institusional melainkan cenderung individual. Oleh karena itu komitmen tersebut dapat disosialisasikan melalui suatu dokumen orgnaisasi yang dinamakan sebagai standard operating procedure (SOP) yakni pedoman prosedur pelaksanaan, instruksi kerja maupun tolok ukur dalam melakukan tindakan dan pekerjaan. Komitmen pimpinan terwakili dalam materi SOP yang harus ditaati anggota, karena berupa kebijakan, program operasional dan kegiatan organisasi.

Implementasi organisasi (mitra) mencakup beberapa tahap yakni tahap pengaktifan strategi, tahap evaluasi strategi dan pengendalian strategi (Sharplin, 1985: 115). Akdon (2006) merinci strategi pengendalian ini dengan sistem pemantauan dan sistem pengawasan. Dalam konteks pengaktifan strategi tidak terlepas dari persoalan struktur organisasi, kebijakan, komitmen pada sumber daya, power, politik, kepemimpinan dan budaya organisasi.

Sistem pemantauan dalam strategi implementasi berupa pengecekan kesesuaian atau penyimpangan antara pelaksanaan dan rencana.Fungsi pemantuan diantaranya:

a. Mengecek tingkat kepatuhan (compliance) dalam rangka azas disiplin

b. Mengaudit penggunaan sumber daya dan tingkat output yang tercapai

c. Memperoleh informasi atas kendala dan problem di lapangan

Sementara itu sistem pengawasan diselenggarakan secara sistematis dan obyektif untuk mencari tahu hal-hal sebagai berikut:

a. Apakah informasi menyangkut jalannya kegiatan yang diperoleh dapat dipercaya? 
b. Resiko yang mungkin muncul dan tindakan untuk mengatasinya

c. Standar yang ada telah diikuti sebagaiman mestinya atau tidak

d. Efektivitas dan efiisiensi pendayagunaan sumber daya organisasi

e. Ketercapaian tujuan dan sasaran Renstra yang telah dirumuskan

Sistem pemantauan dan sistem pengawasan merupakan bagian utuh dari strategi pengendalian dalam upaya memuluskan dan melancarkan implementasi strategi (mitra) yang telah disusun organisasi. Pencapaian tujuan organisasi yang tertuang dalam visi dan misi hanya akan dapat dicapai jikalau kesenjangan antara Renstra dan mitra tidak besar. Dalam konteks pengembangan organisasi di UIN Malang segala segi perubahan (budaya) perlu dicermati secara seksama. Ketergantungan organisasi pada kepiawaian pemimpin semata tidak sejalan dengan standar manajemen modern.

\section{Strategi Perubahan Budaya Organisasi di UIN Maliki Malang}

Strategi perubahan organisasii menjadi bagian penting guna tercapainya visi misi UIN Maliki Malang yang telah mengalami metamorfosis berkelanjutan mulai dari bentuk sekolah tinggi, institut, kemudian universitas hingga dalam menjadi UIN Maliki Malang sekarang ini. Perubahan yang bersifat pengembangan ini relatif cepat dan tentu sangat memerlukan penanganan saksama agar tujuan mulia untuk meningkatkan mutu pendidikan di lembaga pendidikan Islam terwujud.

Sumber-sumber daya yang tersedia harus dimanfaatkan semaksimal mungkin.Kepemimpinan organisasi di tubuh UIN Maliki Malang juga perlu diberdayakan dan dijalankan sesuai dengan kaidah manajemen modern bersinar ajaran mulia dari al Quran dan Hadist. Konsep-konsep peningkatan mutu manajemen dengan berbagai model dan pendekatan yang tersedia dapat diejawantahkan dalam format budaya bernafaskan nilai-nilai Islami. Setiap bentuk model manajemen modern seperti manajemen strategik bagi kiranya perlu diadopsi sesuai situasinya.

Dalam manajemen modern, kepedulian terhadap kekuatan atau proses sosialisasi dalam organisasi semakin besar. Sosialisasi ini meliputi pengembangan persepsi, nilai dan kepercayaan terhadap organisasi serta pengaruh kondisi/keadaan dalam organisasi terhadap perilaku anggota. Untuk mencapai keberhasilan, suatu organisasi harus dikembangkan kepercayaan, sejumlah nilai, norma, tradisi dan kebiasaan yang unik dari suatu organisasi yakni saling percaya (trust), hubungan timbal balik (subtlety) dan keakraban 
(intimacy) antar anggota (Robbins 1996: 290).

Budaya organisasi jika diaplikasikan pada lingkungan manajemen organisasi, lahir konsep budaya manajemen Jika budaya organisasi diterapkan pada lingkungan manajemen organisasi sekolah, maka lahirlah konsep budaya manajemen sekolah dan jika diterapkan di perguruan tinggi menjadi budaya manajemen perguruan tinggi.

Berdasarkan sifatnya, budaya organisasi dapat dibedakan sebagai berikut:

1. Budaya kuat. Dalam suatu budaya kuat, nilai inti organisasi itu dipegang secara intensif dan dianut bersama secara meluas. Makin banyak anggota yang menerima nilai-nilai dan makin besar komitmen mereka pada nilai-nilai itu, makin kuat budaya tersebut. Konsisten dengan definisi ini, suatu budaya kuat akan mempunyai pengaruh yang besar pula pada perilaku anggota-anggotanya karena tingginya tingkat kebersamaan (sharedness) dan intensitas menciptakan suatu iklim internal dari kendali perilaku yang tinggi.

2. Budaya lemah. Kebalikan budaya kuat, adalah budaya lemah, tingkat konsistensi anggotanya tidak lagi kuat dan jangkauan budaya yang telah disepakati tidak lagi luas mencakup seluruh anggota-anggotanya. Dalam kondisi ini mudah diramalkan (predictability), bahwa tujuan yang hendak dicapai melalui tradisi yang telah disepakati akan sulit terwujud (Robbins, 1996: 290).

Kedua sifat budaya organisasi di atas yakni budaya kuat dan budaya lemah di dalam tataran perubahan organisasi berpengaruh secara signifikan. Budaya kuat bisa menjadi halangan perubahan jikalau budaya tersebut bertentangan dengan nilai dan tradisi yang mesti dimiliki anggota dalam proses perubahan. Demikian pula budaya lemah yang melingkupi anggota organisasi yakni apabila tidak mendukung tercapainya tujuan perubahan dapat saja mempersulit terjadinya perubahan yang diharapkan. Oleh karena itu, setiap organisasi yang memiliki rencana strategis merubah arah organisasi terlebih dahulu perlu mempersiapkan anggota organisasinya pada budaya yang sesuai dan menunjang bagi tercapainya tujuan organisasi. Dalam konteks UIN Maliki Malang tidak semua tradisi atau kebiasaan lama yang diabaikan seperti hafalan-hafalan al Quran yang dilakukan mahasiswa pada semestersemester awal. Tradisi ini perlu terus dipelihara dan dilanjutkan kearah yang lebih baik lagi.

Budaya organisasi mengacu pada sekumpulan keyakinan bersama, 
nilai, sikap dan tata hubungan serta asumsi-asumsi yang secara eksplisit atau implisit dapat diterima dan digunakan oleh keseluruhan anggota organisasi baik tatkala berinteraksi dengan sejawat maupun menghadapi lingkungan luar dalam upaya mencapai tujuandan mewujudkan visi organisasi. Dalam hal ini, budaya organisasi mempunyai pengaruh penting terhadap motivasi (Robbins, 1996: 290-291).

\section{Strategi Generik Perubahan Budaya}

Secara umum Paul Bate menawarkan 4 (empat) pendekatan perubahan budaya yaitu:

a. Pendekatan agresif (Aggressive approach); Perubahan budaya dengan menggunakan pendekatan kekuasaan, non-kolaboratif, membuat konflik, sifatnya dipaksakan, sifatnya win-lose, unilateral dan menggunakan dekrit. Menurut Schein disebut pendekatan structural karena mencabut akar-akar budaya yang ada.

b. Pendekatan jalan damai (Conciliative approach); Perubahan budaya dilakukan secara kolaboratif, dipecahkan bersama, win-win, integratif dan memperkenalkan budaya yang baru terlebih dahulu sebelum mengganti budaya yang lama

c. Pendekatan korosif (Corrosive approach; Perubahan budaya yang dilakukan dengan pendekatan informal, evolutif, tidak terencana, politis, koalisi dan mengandalkan networking. Budaya lama sedikit demi sedikit dirusak dan diganti dengan budaya baru

d. Pendekatan indoktrinasi (Indoctrinative approach); Pendekatan yang bersifat normatif dengan menggunakan program pelatihan dan pendidikan ulang terhadap pemahaman budaya yang baru ( mshohib.staff. umm.ac.id/files/2010/03/Budaya-Organisasi).

Memerhatikan strategi perubahan di atas UIN Maliki Malang tidak menggunakan pendekatan agresif melainkan melakukan ketiga pendekatan lainnya yang disebut di atas. Hal ini dikarenakan budaya organisasi lama di UIN Maliki Malang sangat kuat melekat sehingga memerlukan proses yang tidak drastis. Dengan berubahnya STAIN Malang menjadi IAIN lalu UIIS terakhir menjadi UIN Maliki Malang tentu membawa sejumlah implikasi terhadap berbagai bentuk perubahan dan pengembangan di lembaga perguruan tinggi Islam ini. Pengembangan yang memang diharapkan seiring dengan perubahan status lembaga pendidikan Islam ini adalah terkait dengan nilainilai dan budaya bernafaskan keislaman. 
Berbeda dengan di beberapa tempat lain, UIN Maliki Malang berusaha memformat diri menjadi lembaga pendidikan tinggi Islam ideal. Pikiran-pikiran yang pijakan selama ini adalah bahwa perguruan tinggi Islam seharusnya mampu mengantarkan mahasiswa memiliki empat kekuatan, yaitu: (1) kedalaman spiritual, (2) keagungan akhlaq, (3) keluasan ilmu dan (4) kematangan profesional (http://www.uin-malang.ac.id diakses 2 Nopember 2011). Untuk membangun semua kekuatan itu, UIN Maliki Malang berusaha menggabungkan tradisi pesantren dan tradisi perguruan tinggi, dan itulah nantinya yang diharapkan lahir sosok perguruan tinggi Islam yang ideal itu. Selama ini perguruan tinggi lebih menekankan aspek akademik, sedangkan pesantren lebih mengedepankan akhlak dan spiritual lewat kultur yang dikembangkan. Jika kedua kekuatan ini (tradisi kampus dan pesantren) dipadukan maka diharapkan lahir budaya Islami yang mendekati ideal sebagaimana yang ditunggu-tunggu kehadirannya oleh umat Islam di Indonesia.

Berangkat dari visi dan misi UIN Maliki Malang terdapat sejumlah nilainilai budaya bernafaskan Islam dan bersifat universal yang patut ditumbuhsuburkan di kalangan civitas akademika. Beberapa contoh nilai sosial budaya yang perlu menjadi perhatian kepemimpinan UIN Maliki Malang adalah sebagai berikut:

Pertama, etika. Etika atau akhlakul karimah adalah tata aturan untuk bisa hidup bersama orang lain. Kita hidup tidak sendirian, dilahirkan oleh dan dari orang lain yang bernama ibu dan ayah kita, dan kemudian hidup bersama dengan orang lain. Untuk mendukung pernyataan ini berikut adalah Hadist Nabi yang artinya sebagai berikut: "Orang mukmin yang paling sempurna imannya adalah yang paling baik akhlaknya" (HR. at-Tirmidzi no. 1082. Dishahihkan asy-Syaikh al-Albani Rahimahullahu dalam Shahih al-Jami' no. 1232).

Kedua, kejujuran. Semua warga Perguruan Tinggi harus dilatih berbuat jujur, mulai jujur kepada dirinya sendiri, jujur kepada Tuhan, jujur kepada orang lain. Kejujuran itu harus dibangun di Perguruan Tinggi. Bukan sebaliknya. Dari tinjauan inilah barangkali perlu membuat program kantin kejujuran di Perguruan Tinggi ini. Konon, materi materi mata pelajaran matematika modern seharusnya menghasilkan manusia yang jujur di negeri ini. Apalagi dengan materi pelajaran Pendidikan Agama. Tetapi nyatanya tidak demikian. Malah telah menghasilkan banyak koruptor. Materi tentang penjumlahan, pengurangan, dan perkalian ternyata jauh lebih mudah dibandingkan dengan materi tentang pembagian. Hasilnya, membagi kasih sayang, membagi pemerataan, dan membagi kebahagiaan ternyata jarang dilakukan ketimbang mengumpulkan hasil korupsi, mengalikan bunga bank untuk kekayaan pribadi. Oleh karena 
itu, maka budaya kejujuran harus dapat dibangun di Perguruan Tinggi.

Ketiga, kasih sayang. Ada tiga landasan pendidikan yang harus dibangun, yaitu (1) kasih sayang, (2) kepercayaan, dan (3) kewibawaan. Kasih sayang telah melahirkan kepercayaan. Kepercayaan menghasilkan kewibawaan.

Keempat, mencintai belajar. Mana yang lebih penting antara menguasai pelajaran atau mencintai belajar? Learning how to learn, ternyata akan jauh lebih penting ketimbang bersusah payah menghafalkan bahan ajar yang selalu terus bertambah itu. Dari sini lahirlah pendapat bahwa belajar konsep jauh lebih penting daripada menghafalkan fakta dan data.

Kelima, bertanggung jawab. Sering kali kita menuntut hak ketimbang tanggung jawab. Mahatma Gandhi mengingatkan bahwa semua hak itu berasal dari kewajiban yang telah dilaksanakan dengan baik.Itulah sebabnya maka kita harus memupuk rasa tanggung jawab ini sejak dini ini di lembaga pendidikan Perguruan Tinggi, bahkan dari keluarga.

Keenam, menghormati hukum dan peraturan.Sering kita menghormati hukum dan peraturan karena takut kepada para penegak hukum. Kita mematuhi hukum dan perundang-undangan karena takut terhadap ancaman hukuman.Seharusnya, kita menghormati hukum dan peraturan atas dasar kesadaran bahwa hukum dan peraturan itu adalah kita buat untuk kebaikan hidup kita.

Ketujuh, menghormati hak orang lain. Fenomena membeda-bedakan orang lain karena berbagai kepentingan. Mesti disadari bahwa sebagian dari apa yang kita peroleh adalah hak orang lain. Kita sering mementingkan diri sendiri ketimbang memberikan penghargaan kepada orang lain. Oleh karena itu penghargaan kepada orang lain tidak boleh melihat perbedaan status sosial, ekonomi, agama, dan budaya.

Kedelapan, mencintai pekerjaan. Ingin berbahagia selamanya, maka bekerjalah dengan senang hati. Ini adalah kata-kata mutiara yang selalu melekat di hati.Pekerjaan adalah bagian penting dari kehidupan ini. Siapa yang tidak bekerja adalah "tidak hidup". Oleh karena itu, mahasiswa harus diberikan kesadaran tentang pentingnya menghargai pekerjaan.

Kesembilan, suka bekerja keras. Ngobrol dan duduk-duduk santai adalah kebiasaan lama di pedesaan kita. Pagi-pagi masih berkerudung sarung. Padahal, setelah shalat Subuh, kita diharuskan bertebaran di muka bumi untuk bekerja. Untuk ini, suka bekerja keras harus menjadi bagian dari pendidikan mahasiswa kita di Perguruan Tinggi dan di rumah.

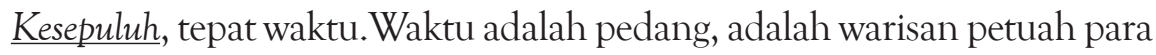


sahabat Nabi. Time is money adalah warisan budaya para penjelajah ekonomi (kapitalis) bangsa-bangsa Barat. Sebaliknya, jam karet adalah istilah sehari-hari bangsa sendiri yang sampai saat ini kita warisi.

Mengamati UIN Malang secara cermat akan tampak berbagai kelemahannya terutama bila disandarkan pada kesepuluh nilai-nilai budaya Islami tersebut di atas. Masih ditemukan civitas akademika UIN yang abai atas nilai-nilai etika, kejujuran, kasih sayang, tekun belajar, tanggung jawab, hormat hukum dan hak orang lain, mencintai pekerjaan dengan melayani mahasiswa sepenuh hati, kerja keras, dan tepat waktu. Kejadian perseteruan bahkan perkelahian mahasiswa di lungkungan kampus menandai terpuruknya akhlak karimah di UIN Malang. Belum lagi perilaku mahasiswa yang merokok di ruang publik seperti di tempat parkir kendaraan bermotor cukup mengkhawatirkan baik dari sisi keamanan dan kenyamanan orang lain. Dalam kasus ini tidak tampak nilainilai Islaminya. Standar pelayanan tenaga pendidik dan kependidikan masih mengabaikan prinsip-prinsip manajemen modern diantaranya melaksanakan pelayanan prima (service excellent). Disisi lain implementasi manajemen strategik belum berjalan sesuai harapan.

\section{Implementasi Manajemen Strategik UIN Maliki Malang}

\section{A. Menformulasikan Strategi}

UIN Maliki Malang telah memiliki visi dan misi yang dalam konsep manajemen strategik berada pada fase memformulasikan strategi yang mencakup arah tujuan organisasi. Visi dan misi UIN Maliki Malang sebagai berikut:

Visi Universitas adalah menjadi universitas Islam terkemuka dalam penyelenggaraan pendidikan dan pengajaran, penelitian, dan pengabdian kepada masyarakat untuk menghasilkan lulusan yang memiliki kedalaman spiritual, keluhuran akhlak, keluasan ilmu, dan kematangan profesional, dan menjadi pusat pengembangan ilmu pengetahuan, teknologi, dan seni yang bernafaskan Islam serta menjadi penggerak kemajuan masyarakat

Sedangkan Misi UIN Maliki Malang adalah:

1. Mengantarkan mahasiswa memiliki kedalaman spiritual, keluhuran akhlak, keluasan ilmu, dan kematangan profesional.

2. Memberikan pelayanan dan penghargaan kepada penggali ilmu pengetahuan, khususnya ilmu pengetahuan dan teknologi serta seni yang bernafaskan Islam.

3. Mengembangkan ilmu pengetahuan, teknologi, dan seni melalui pengkajian dan penelitian ilmiah.

4. Menjunjung tinggi, mengamalkan, dan memberikan keteladanan dalam kehidupan atas dasar nilai-nilai Islam dan budaya luhur bangsa Indonesia

Lalu tradisi UIN Maliki Malang yakni perilaku sivitas akademika dalam 
melakukan perannya didasari oleh kesadaran tinggi dalam meraih cita-cita bersama. Penjabaran tradisi terdiri dari (1) penampilan fisik; (2) kelembagaan; (3) profil dosen (4) profil pegawai; (5) mahasiswa; (6) profil lulusan yang diharapkan; (7) sentra kegiatan yang dikembangkan; (8) fungsi masjid dan ma'had (9) pengembangan dosen (10) pengembangan perpustakaan; (11) kemampuan ideal akademik dosen; (12) hubungan di dalam kampus; dan (13) hubungan sivitas akademika dengan lembaga.

Visi dan misi UIN Maliki Malang tidak lepas dari buah pikiran cemerlang Prof. Imam Suprayogo yang menjabat Rektor selama empat periode yang berakhir pada Mei 2013. Gagasan, ide dan pandangan beliau kemudian dituangkan dalam bentuk visi dan misi organisasi. Dominasi visi misi organisasi UIN Maliki Malang terletak pada sang Rektor saat itu demikian pula dalam implementasi dari visi dan misi organisasi yang mengandalkan kekuatan pemimpin. Kondisi dalam organisasi sendiri memang memungkinkan diterapkannya kepemimpinan model autocracy agar ide dan gagasan yang telah dituangkan dapat diejawantahkan menjadi programprogram nyata. Justru dengan model tersebut organisasi UIN Maliki Malang berjalan dengan baik dan dikenal sebagai UIN yang progresif dalam meningkatkan kinerjanya.

Pada tahap formulasi strategi diperlukan penjabaran dari hasil SWOT yang dalam konsep manajemen strategik perlu dibuat secara transparan dan disosialisasikan agar jajaran pimpinan memahaminya. Terkait dengan formulasi strategi ini perlu dibuatkan rencana jangka pendek, menengah dan jangka panjang yang dijabarkan secara terbuka, transparan dan dikomunikasikan kepada pihakpihak terkait. Konsep manajemen strategik ini tidak sepenuhnya dijalankan dalam konteks perubahan organisasi yang terjadi di UIN Maliki Malang. Kecepatan bergerak untuk segera mengambil keputusan dan memanfaatkan peluang senantiasa dilakukan Prof. Imam Suprayogo pada saat memimpin yang acapkali memang tidak sejalan dengan teori dan konsep manajemen strategik. Namun hal ini harus dilakukan sang Rektor mengingat sumber-sumber internal belum mencukupi baik dari sisi kuantitas maupun kualitas, sehingga kemajuan organisasi dapat diarasakan hingga kini.

Guna mengelaborasi buah pikiran sang Rektor dibuatlah rancangan tentang pohon ilmu. Bangunan keilmuan yang dikembangkan berupa pohon yang tumbuh subur, besar dan rindang serta berbuah yang segar. Sebagai layaknya pohon selalu memiliki akar, batang, dahan, ranting, daun dan buah yang sehat dan segar. Akar digunakan untuk menggambarkan ilmu instrumental yang harus dikuasai terlebih dahulu. Ia merupakan alat atau instrumen, maka harus dipersiapkan secara matang sebelum menjamah lainnya. Ilmu instrumental itu meliputi kemampuan bahasa 
bahasa Indonesia, Bahasa Arab dan Bahasa Inggris, logika atau ilmu mantiq, ilmu pengetahuan alam dan ilmu pengetahuan sosial, sekalipun pada tingkat dasar. Batang digunakan untuk untuk menggambarkan ilmu tentang Islam, meliputi al Qur'an, Hadits, Sirah Nabawiyah dan pemikiran Islam. Semua ilmu yang digambarkan dalam metafora sebagai batang dan akar sebuah pohon besar tersebut sifatnya fardhu ain bagi seluruh mahasiswa mempelajari dan menguasainya. Sedangkan dahan, ranting dan daun yang bercabang-cabang banyak menggambarkan ilmu-ilmu modern yang harus dipilih oleh setiap mahasiswa secara-berbeda-beda. Oleh karena itu mempelajarinya bersifat fardhu kifayah. Sedangkan buah pohon itu untuk menggambarkan hasil dari proses pendidikan yang dikembangkan yaitu iman, amal sholeh dan akhlakul karimah. Lulusan yang diharapkan lahir dirumuskan dalam bentuk perintah sebagai berikut: kunuи ulil ilmi, kunuи ulil an nuha, kunuu ulil abshar, kunuu ulil al baab, wajahidu fillah haqqa jihadihi. Kalimat ini ditulis pada prasasti yang diletakkan didepan pintu masuk Ma'had agar semua santri (mahasiswa) selalu membaca dan mengingat akan tujuan kampus perguruan tinggi Islam ini dibangun yang dalam Bahasa Indonesianya kurang lebih bermakna, "jadilah orang yang berilmu, orang yang berpikir, berzikir, berakhlak mulia dan beramal, serta berjihadlah karena Allah dengan sebenar-benarnya jihad".

Apa yang dipaparkan di atas merupakan bagian dari formulasi startegi dalam konsep manajemen strategik. Dalam konteks ini UIN Maliki Malang telah memformulasikan strategi dengan baik dan lengkap. Persoalan kemudian yang muncul adalah kesesuaian antara perencanaan strategik (strategic planning) dan implementasi strategi (strategy implementation). Implementasi terkait dengan bentuk pengawasan, pengendalian dan evaluasi yang merupakan langkah-langkah yang perlu dilakukan.

\section{B. Mengimplementasikan Strategi}

Setelah dilakukan perumusan strategi tahap berikutnya adalah melakukan implementasi strategi, cara mencapai tujuan dan sasaran dalam bentuk strategi implementasi yang selanjutnya diperinci ke dalam kebijakan, program operasional dan kegiatan. Pada kasus UIN Maliki Malang penetapan program-program strategik "dikuasai” npimpinan Universitas. Program-program tersebut secara teori di elaborasi dan atau didapat dari sejumlah strategi organisasi yang telah berhasil dirumuskan.

Sebagaimana para ahli menekankan pentingya untuk mengimpementasikan strategi yang telah diformulasikan tersebut ke dalam unit-unit atau fungsi-fungsi yang terdapat dalam organisasi. Namun 
pada kasus UIN Maliki Malang strategi implementasi yang sebenarnya bersifat menterjemahkan pemikiran dalam renstra (rencana strategik) ke dalam tindakan operasional sehari hari belum tampak diejawantahkan dalam program-program internal yang terstruktur dan sistematis.

Dalamsetiap pelaksanaan manajemenstrategik kerapterjadiketidakharmonisan, kesenjangan atau ketimpangan antara tujuan organisasi dan anggota organisasi. Begitu pula fenomena yang terjadi di UIN Maliki Malang. Paradoks dan kontradiksi semacam itu biasa mencuat di organisasi manapun tak terkecuali pada sektor pendidikan. Bagian berikut ini akan mengkaji hal-hal terkait antara das sein dan das sollen, antara fakta dan harapan dalam perubahan organisasi di UIN Maliki Malang.

\section{Kajian Kritis atas Implementasi Manajemen Strategik di UIN Maliki Malang}

Pembahasan mengenai implementasi manajemen strategik di atas mengandalkan perubahan yang terukur dan meninggalkan pemahaman bahwa perubahan di UIN Maliki Malang masih belum maksimal memanfaatkan kaidah dalam manajemen strategik. Hal ini disadari mengingat sasaran antara masing-masing pihak (program objectives) yang berada di lingkungan UIN itu tidak diturunkan menjadi program-program yang berdasar pada SMART (Specific, Measureable, Attainable, Realistic, Time bounded). Ini berarti semua program mesti dibuat secara jelas (spesifik), dapat diukur, dapat diperoleh, realistis dan memiliki batasa waktu. Berikut ini paling terdapat sejumlah hal yang patut dikritisi dari hasil paparan hasil studi tersebut:

1. Penulisan visi, misi, tradisi hingga ke buku kecil berjudul mimpimimpi UIN Malang terkesan seolah-olah tidak disusun berdasar konsep manajemen strategik seperti memerhatikan asesmen atau analisis faktor-faktor internal dan eksternal organisasi, sehingga terdapat poin yang kurang memenuhi kaidah SMART dalam programprogram yang akan diwujudnyatakan.

2. Kepemimpinan individu "one man show" terkesan menonjol, sehingga motor penggerak organisasi hanya pada perseorangan belum menjadi satu kesatuan. Hal ini dapat dilihat dari tersusunnya buku berisi mimpi-mimpi UIN yang disandingkan dengan visi misi tetapi ternyata buku tersebut dalam konsep manajemen strategik dikenal dengan tujuan program (program objectives) dan toloh ukur keberhasi- 
lan program. Semestinya program objectives adalah turunan dari formulasi strategi perencanaan yang bersandar pada misi UIN Maliki Malang.

3. Dari kedua buku yang menjadi acuan umum warga UIN Malang melakukan kegiatannya memang terdapat analisis kekuatan dan kelemahan namun masih bersifat parsial dan tidak terfokus, demikian pula tantangan dan peluang yang dihadapi UIN Malang belum dijabarkan secara baik mengikuti model analisis SWOT. Konsekuensinya, belum tampak program-program mendesak dan penting untuk dikerjakan terlebih dahulu seperti pembentukan budaya Islami

4. Pengembangan budaya Islami sebagai bagian utama dan penting untuk yang pertama kali diperhatikan guna mencapai tujuan visi dan misi ternyata tidak ada cetak biru/blueprint atau langkah strategi (road map) untuk mencapainya.

Dari sisi konsep penanganan perubahaan organisasi atau standar manajemen perubahan maka dibawah ini merupakan kondisi realita yang cenderung terjadi di organisasi UIN Maliki Malang:

1. Autocracy adalah organisasi yang mengandalkan "kekuatan" pemimpin. Kewenangan pemimpin tinggi, bila pemimpin tidak mengijinkan maka tidak boleh dilakukan begitu sebaliknya. Sedangkan diujung sebelah kanan adalah organisasi Egalitarianism. Pada organisasi ini seluruh keputusan ada di tangan anggota organisasi, hampir tidak diperlukan pemimpin, tugas pemimpin hanya memfasilitasi saja terhadap diambilnya sebuah keputusan. Dalam kasus UIN Maliki Malang sebagaimana yang telah diulas tampak sekali peran pimpinan (Rektor) yang demikian dominan. Kecenderungan dari tipe organisasi UIN Maliki Malang saat ini adalah bersifat ke arah Autocracy, walau terdapat pula situasi yang memungkinkan keputusan dilaksanakan oleh anggota organisasi

2. Perubahan organisasi yang kurang dikelola menurut standar manajemen perubahan sebagaimana diuraikan diatas memungkinkan munculnya kesenjangan pemahaman, informasi dan kualitas personal antara jajaran pimpinan dan anggota organisasi lainnya.

3. Pengembangan budaya organisasi hanya akan efektif apabila tiga kekuatan berperan sama baik yakni: praktik seleksi, tindakan manajemen puncak dan metode sosialisasi (Harrison dan dalam Mardiyah, 2012: 83). Seleksi dimaksudkan mempekerjakan individu yang mumpuni 
dalam organisasi. Sedang tindakan manajemen puncak mempunyai dampak besar pada budaya organisasi. Lalu sosialisasi adalah proses mengenal-adaptasikan seluruh anggota pada budaya organisasi yang menjadi acuan baik pada manajemen strategik maupun manajemen perubahan.

\section{Simpulan}

Artikel ini menghasilkan kesimpulan bahwa manajermen strategik dan manajemen perubahan merupakan dua konsep manajemen yang saling melengkapi dan senantiasa berkaitan dengan peningkatan kualtas organisasi. Referensi atau literatur tentang manajemen selalu mendefiniskan dan mengartikan manajemen dengan tidak melepaskannya dari segala keunikan dan ciri-ciri khas yang dimiliki masing-masing individu (individual differences). Oleh karena itu manajemen sebagai suatu seni mengelola dengan, melalui dan bersama orang lain atau the art of getting through with people. Bufort dan Bedeian dalam Sonhadji (2003) sebagaimana diuraikan diatas mengemukakan makna dari manajemen tersebut sebagai proses pencapaian tujuan melalui pendayagunaan sumber daya manusia dan material secara efisien.

Dalam mencapai tujuan manajemen yang juga sekaligus merupakan tujuan organisasi mengefektivitaskan sumber daya dipandang penting. Oleh karena itu muncul model manajemen strategik yaitu proses merumuskan rencana dan menerapkan kegiatan yang berdampak pada tumbuh dan berkembangnya organisasi termasuk keberlangsungannya secara keseluruhan. Pada kasus UIN Maliki Malang pendekatan manajemen strategik tidak digunakan menyeluruh dan tidak sepenuhnya sejalan dengan konsep manajemen perubahan.

UIN Malang secara organisasi masih terpaku pada kehandalan dan kepiawaian tokoh, sehingga praktek "one man show" kerap mendominasi implementasi dari manajemen strategik yang sebenarnya sudah dirancang dan disusun dengan baik. UIN Maliki Malang yang tumbuh-kembang dengan pesat tidak dapat dipungkiri lebih banyak bersandar pada kiprah dan peran utama dari pimpinan (Rektor). Faktor kepemimpinan memang diperlukan dalam manajemen strategik tetapi tidak cukup tanpa ditunjang dengan sistem yang sudah terinstitusionalisasi. Perubahan dan pengembangan budaya Islami bagi sivitas akademika di UIN Maliki Malang masih pekerjaan rumah yang tertinggal.

Saran-saran berdasarkan kajian manajemen strategik antara lain:

1. Perlu dikaji kembali visi dan misi dengan melibatkan seluruh komponen 
pemangku kebijakan di UIN Malangberikut dengan program, SOP dan lain.

2. Penyusunan program dan kegiatan yang dilakukan semestinya memerhatikan kaidah SMART agar pencapaian tujuan menjadi lebih mudah dan obyektif

3. Budaya Islami merupakan bagian penting yang membedakan UIN Malang dengan lembaga Perguruan Tinggi non Islam lain yang tidak bersandarkan nilai Islami, oleh karena itu diperlukan perangkat dan alat untuk membumikan nilai-nilai Islami yang menopang budaya kerja yang diharapkan guna tercapainya visi dan misi UIN Malang.

\section{Daftar Pustaka}

Akdon. (2006). Strategic Management for Educational Management (Manajemen Strategik untuk Manajemen Pendidikan). Bandung: ALFABETA.

Ansoff, H. Igor \& McDonnel, Edward J. (1990).Implanting Strategic Management. UK:Prentice.

Anthony-Darden-Bedford. (1992).Sistem Pengendalian Manajemen, Jakarta: Bina Rupa Aksara.

Freeman, R.E. (1995). Manajemen Strategik. Jakarta: PT. Pustaka Binaman Pressindo.

Kasali, Renald. 2006. Change. Jakarta: Gramedia.

Lewis, James, (1983). Long-Range and Short-Range Planning for Educational Administrators, Massachusetts: Allyn and Bacon Inc.

Luthans, Fred (1992). Organizational Behavior. Sixth edition, McGraw-Hill, Singapore.International Edition.

Mardiyah (2012). Kepemimpinan Kyai dalam Memelihara Budaya Organisasi. Malang. Aditya.

Musnandar, Aries. Perubahan Organisasi Perguruan Tinggi Islam di Indonesia Dalam Menghadapi Persaingan Global. Jurnal Ulul Albab. Vol 12, No. 2. Tahun 2011.

Ndraha, Taliziduhu. (1997). Budaya Organisasi. Jakarta: PT. Rineka Cipta. 
Owens, Robert. (1987). Organizational Behaviorin Education. New Jersey. Prentice Hall.

Pearce II, John A. \& Robinson Jr, Richard B. (1991).Strategic Management: Formulation, Implementation, and Control. Boston: Irwin.

Sharplin, Arthur, (1985). Strategic Management.Singapore: McGraw-Hill Book Co.

Siagian, Sondang P., (2005). Manajemen Stratejik. Jakarta: PT. Bumi Aksara

Slamet Raharjo (2004). Memadu Sains dan Agama Menuju Universitas Islam Masa Depan, Kerja sama UIN Malang dengan Bayumedia.

Soekarto Indrafachrudi (1994), Bagaimana Mengakrabkan Sekolah dengan Orang Tua Murid dan Masyarakat, Malang, IKIP Malang.

Sonhadji, Ahmad, (2003). Modul Analisis Swot: Suatu Analisis Lingkungan Dengan Menggunakan Manajemen Strategik. Program Pascasarjana, Universitas Negeri Malang.

Sonhadji, Ahmad, (2003). Modul Manajemen Strategik: Formulasi dan Implementasi Strategi, Program Pascasarjana, Universitas Negeri Malang.

Stephen P. Robbins (1996). Perilaku Organisasi Konsep Kontroversi Aplikasi, Jilid 2, Edisi Bahasa Indonesia, Jakarta, PT Prenhallindo.

Suprayogo, Imam. Mimpi-mimpi UIN Malang Menuju Prestasi Gemilang

Visi, Misi, dan Tradisi Universitas Islam Negeri Maulana Malik Ibrahim Malang. (2010).

Kumpulan Materi Matakuliah Kewirausahaan SWOT atau analisa KeKePan oleh Aries Musnandar, FE UB Malang (2007-2011).

Departemen Pendidikan dan Kebudayaan, Kamus Besar Bahasa Indonesia, 1991. 